\title{
28 Research Square \\ Comparative study for Treatment of Domestic Wastewater Using Chlorella Vulgaris
}

\section{Nandini Moondra}

Sardar Vallabhbhai National Institute of Technology

Namrata Jariwala ( $\nabla$ ndj@ced.svnit.ac.in )

Sardar Vallabhbhai National Institute of Technology https://orcid.org/0000-0002-1702-0046

\section{Robin A Christian}

Sardar Vallabhbhai National Institute of Technology

\section{Research}

Keywords: Chlorella vulgaris, nutrient removal, domestic wastewater, eco- friendly

Posted Date: May 11th, 2020

DOI: https://doi.org/10.21203/rs.3.rs-25555/v1

License: (1) This work is licensed under a Creative Commons Attribution 4.0 International License. Read Full License 


\section{Abstract}

Tertiary treatment using chemicals frequently prompts secondary contamination of sludge, making other issues of safe disposal. Thus, vitality and cost required for tertiary treatment of wastewater stay an issue for industries and municipalities. In this study, different microalgal concentrations $(20 \%, 25 \%, 30 \%, 35 \%$, $40 \%$ and $45 \%$ ) were studied to treat domestic wastewater at 11 hours HRT for both filtered and nonfiltered effluent. During the study, removal was observed in Total Solids (TS), Total Dissolved Solids (TDS), Total Suspended Solids (TSS), Electrical Conductivity (EC), phosphate, ammonia and COD for all the microalgal concentrations mentioned. However, the maximum removal efficiency was observed at $30 \%$ microalgal concentration. Maximum removal efficiency found in ammonia, phosphate and COD for non-filtered effluent was $96.60 \%, 91.73 \%$ and $84.71 \%$ respectively, whereas, in the case of the filtered sample, removal efficiency reached up to $97.62 \%, 92.47 \%$ and $88.75 \%$ for ammonia, phosphate and COD respectively. In the case of solids (specifically TSS) and EC, removal efficiency reached up to $30.87 \%$ and $24.31 \%$ respectively for non-filtered effluent and was $48.00 \%$ and $25.88 \%$ in the filtered sample. The study showed that an algae-based system could accomplish more affordable and environment-friendly way to treat domestic wastewater without tertiary treatment to a desirable limit.

\section{Introduction}

The world will confront $40 \%$ water deficiency by 2030 , which is a challenge for sustainable development $[1,2]$. This shortfall may emerge from the expanding interest for water, degradation of water assets and the absence of innovations to recover the used water. Water contamination is a joined after effect of various anthropogenic exercises [3]. The untreated wastewater contains fluctuating degrees of organic and inorganic mixes. The deterioration of water quality when the sewage is discharged into receiving bodies would likewise prompt water shortage, which is a significant issue far and wide. Sewage is the conversion of $70-80 \%$ of the total water supplied for domestic purpose, of different chemical compositions with varying quality and quantity, depending on the source.

In India, 61,754 MLD is the sewage generated against the sewage treatment capacity of 22,963 MLD, owing to the distinct gap between sewage generation and treatment capacity, about 38,791 MLD of untreated sewage ( $62 \%$ of total sewage) is directly discharged into nearby water channels [4]. The wastewaters originating from these point or nonpoint sources, if disposed of in a nearby water body without any treatment, adversely affect the water quality and aquatic ecosystem [5]. Thus, the current need is to minimize the consumption of water as well as to return it to the earth with minimum possible pollution because of the limited potential of self-purification in water bodies [6].

However, most existing sewage treatment processes in developing countries are confronting difficulties

with nitrogen and phosphorus removal to meet the necessities for disposal and water reuse. Conventional nutrients removal methods, such as activated sludge-based treatment process, nitrification-denitrification, chemical phosphorus removal, and coagulating sedimentation are facing difficulties in meeting the stringent nutrient release guidelines effectively at low expenses [4, 7]. Besides, their downsides, for 
example, high vitality utilization, flimsiness treatment impact, long procedure, carbon emanation, excess sludge discharge are additionally obvious obstructions to coordinate the idea of the practical advancement in wastewater treatment with low-carbon, low vitality utilization and asset reusing $[8,9]$.

The most eco-friendly and economical technique for wastewater treatment is with biological methods, where chemical break down and treatment of residues is done by microorganisms also with the production of added-value compounds $[10,11]$. Many studies have proposed microalgae as an alternative biological treatment that efficiently removes nutrients from wastewater [12] even when nutrient concentrations are high [13-16]. Wastewater treatment using microalgae was first described in early 1950s. The term "phycoremediation" was coined by John in 2000 to address bioremediation carried out by algae. Municipal wastewater is enriched with a substantial amount of ammonia, phosphate and other essential nutrients which support algal biomass production $[17,18]$.

Literatures have been reported with nitrogen (>90\%) and phosphorus (>50\%) removal using microalgae [11]. Chlorella vulgaris can effectively remove nitrogen (up to $81-85 \%$ ) and phosphorus (32-36\%), respectively [19], Galdieria sulphuraria when used removed ammonia nitrogen (63-89\%) and phosphorus (71-95\%), respectively [20]. The green algae Micractinium $s p$. when used for nutrient removal, it gave efficiency to the system about $>90 \%$ in the case of both phosphorus and nitrogen respectively [13].In the present study, an attempt was made to analyze the effectiveness of the microalgal system if incorporated in wastewater treatment regarding the removal of the different physico-chemical parameters along with nutrients at much lesser Hydraulic Retention Time (HRT) in the Indian context.

\section{Materials And Methods}

Nutrient and organic removal batch study was performed using Chlorella vulgaris in $2 \mathrm{~L}$ glass beakers with a working volume of $1800 \mathrm{~mL}$ at 11 hours HRT as shown in Fig. 1. Different glass beaker with varying microalgal concentrations $360 \mathrm{~mL}(20 \%), 450 \mathrm{~mL}(25 \%), 540 \mathrm{~mL}(30 \%), 630 \mathrm{~mL}(35 \%), 720 \mathrm{~mL}$ $(40 \%)$ and $810 \mathrm{~mL}(45 \%)$ while the remaining volume was made up by the raw domestic wastewater collected from the nearby sewage pumping station at Surat. The study was conducted in an open atmosphere under natural light conditions. External aeration was provided for 10 hours to keep microalgae in suspension, followed by an hour of settling. After the settling period, the supernatant was drawn for physico chemical analysis. The time slot for an 11-hour study was 10:00 hours -21.00 hours, which has both the effect of light and dark phase. The light intensity during this phase was about 6 hours. The study was conducted in a pair of different microalgal concentration, i.e., $20 \%$ and $25 \%, 30 \%$ and $35 \%, 40 \%$ and $45 \%$. Various parameters analyzed during the study (for both the phase) were $\mathrm{pH}$, Electrical Conductivity (EC), Total Dissolved Solids (TDS), Total Solids (TS), Total Suspended Solids (TSS), Chemical Oxygen Demand (COD), phosphate, ammonia, nitrate and Dissolved Oxygen (DO) as prescribed in APHA, 2012 manual. During the initial phase of the study, a faint green tint was observed in the effluent due to the presence of filamentous algae. But with the time, the microalgal settleability improved and the intensity of color decreased to nil. Hence the study was also conducted with the effluent, filtered with a coarse filter $(4-5.5 \mu \mathrm{m})$ to get an idea about the color impartment. The study was 
conducted to analyze the sustainability of the microalgae system to have the effect of both light and dark phases when used in an actual scenario.

\section{Results And Discussion}

During the experimental process, various physico chemical parameters were measured at 11 hours HRT for all the concentrations of $C$. vulgaris $(20 \%, 25 \%, 30 \%, 35 \%, 40 \%$ and $45 \%)$. The average concentration of raw domestic wastewater collected from a nearby sewage pumping station for various parameters studied is tabulated in Table 1.

After the treatment of the raw domestic wastewater with microalgae, it was found that even though with low HRT of 11 hours in the present study, efficient removal was observed in all the parameters analysed at different microalgal concentration when compared with various literatures where the HRTs varied in days to weeks [21-23]. Chlorella vulgaris was used because of its characteristics features like (1) high growth rate, (2) fast nutrient removal rate; (3) strong adaptability to different types of wastewater and local climate; and (4) high biomass productivity [1].After the treatment of the raw domestic wastewater with microalgae, it was found that coupling WWT with algae can be a reasonable, cost-effective viable opportunity for water treatment, with an opportunity for clean water production in areas of water scarcity [24]. Removal in different parameters was observed in each concentration studies. However, maximum removal was found in the effluent of the $30 \%$ microalgae.

Nitrogen is transformed into $\mathrm{N}_{2}$ gas in conventional nitrogen removal methods, whereas in the algal treatment system, nitrogen compounds are taken up for their growth [25]. The uptake of nitrate is light energy-dependent, and also microalgae prefer to utilize already reduced nitrogen, such as ammonium in comparison to nitrate, which is less energy intensive conversion [26]. Ammonia was efficiently removed in the system as it is incorporated into protein via protein anabolism for microalgal growth [27, 28]. Variation in percentage removal efficiency for ammonia at different concentration considered in the study was $59.84 \pm 24.29$ for $20 \%$ concentration, $67.37 \pm 22.44$ for $25 \%$ concentration, $73.65 \pm 24.79$ for $30 \%$ concentration, $69.56 \pm 27.92$ for $35 \%$ concentration, $49.84 \pm 19.50$ for $40 \%$ concentration and $54.37 \pm$ 20.08 for $45 \%$ concentration in case of non- filtered effluent respectively. However, when effluent was filtered with coarse filter to remove filamentous microalgae if any, percentage removal efficiency further increased to $65.63 \pm 23.45$ for $20 \%$ concentration, $71.13 \pm 21.94$ for $25 \%$ concentration, $77.66 \pm 22.64$ for $30 \%$ concentration, $75.27 \pm 24.56$ for $35 \%$ concentration, $55.93 \pm 18.42$ for $40 \%$ concentration and $58.47 \pm$ 19.09 for $45 \%$ concentration respectively shown in Fig. 2(a). Increase in nitrate concentration was observed during the study as ammonia was converted to nitrate in aerobic condition via nitrification [29]. Nitrate concentration raised to $3.47 \mathrm{mg} / \mathrm{L}, 3.82 \mathrm{mg} / \mathrm{L}, 5.87 \mathrm{mg} / \mathrm{L}, 5.82 \mathrm{mg} / \mathrm{L}, 3.85 \mathrm{mg} / \mathrm{L}$ and $3.82 \mathrm{mg} / \mathrm{L}$, when wastewater treated with $20 \%, 25 \%, 30 \%, 35 \%, 40 \%$ and $45 \%$ microalgae respectively.

Microalgae have also shown the great potential to utilize phosphorus from wastewater, but mainly in the form of orthophosphate [30], and it is incorporated into organic compounds such as nucleic acids, phospholipids and proteins [31]. Variation in percentage removal efficiency for phosphate at different 
concentration considered in the study was $60.46 \pm 18.62$ for $20 \%$ concentration, $63.95 \pm 16.17$ for $25 \%$ concentration, $71.47 \pm 17.92$ for $30 \%$ concentration, $69.29 \pm 18.22$ for $35 \%$ concentration, $54.61 \pm 13.16$ for $40 \%$ concentration and $56.14 \pm 13.22$ for $45 \%$ concentration in case of non- filtered effluent. However, when effluent was filtered with a coarse filter to remove filamentous microalgae if any, percentage removal efficiency further increased to $66.27 \pm 15.99$ for $20 \%$ concentration, $69.94 \pm 13.48$ for $25 \%$ concentration, $74.56 \pm 16.98$ for $30 \%$ concentration, $71.33 \pm 18.08$ for $35 \%$ concentration, $57.84 \pm 12.68$ for $40 \%$ concentration and $60.05 \pm 12.87$ for $45 \%$ concentration. Removal efficiency phosphate at different microalgal concentrations is shown in Fig. 2(b).

COD removal is performed in the microalgae system in symbiotic relation with the heterotrophic bacteria [32], as the oxygen produced by algae as an end product is utilised by bacteria for their growth and survival [33]. Variation in removal efficiency for COD at different concentration considered in the study was $52.40 \pm 17.32$ for $20 \%$ concentration, $55.13 \pm 18.88$ for $25 \%$ concentration, $65.13 \pm 20.21$ for $30 \%$ concentration, $62.54 \pm 22.15$ for $35 \%$ concentration, $57.51 \pm 14.94$ for $40 \%$ concentration and $59.35 \pm$ 13.77 for $45 \%$ concentration in case of non- filtered effluent. However, when effluent was filtered with a coarse filter to remove filamentous microalgae if present, percentage removal efficiency further increased to $59.91 \pm 16.34$ for $20 \%$ concentration, $63.59 \pm 15.14$ for $25 \%$ concentration, $69.90 \pm 20.54$ for $30 \%$ concentration, $66.01 \pm 21.60$ for $35 \%$ concentration, $62.01 \pm 12.87$ for $40 \%$ concentration and $64.53 \pm$ 12.94 for $45 \%$ concentration as shown in Fig. 3.

During the study, removal in TS and TSS was also observed to a certain extent due to the formation of algal bacterial biomass that settles down and leaves a clear supernatant. Variation in percentage removal efficiency for TS at different microalgal concentration considered in the study was $11.74 \pm 7.2$ for $20 \%$ concentration, $12.36 \pm 6.6$ for $25 \%$ concentration, $13.72 \pm 4.13$ for $30 \%$ concentration, $11.14 \pm 4.85$ for $35 \%$ concentration, $11.23 \pm 4.77$ for $40 \%$ concentration and $11.53 \pm 5.00$ for $45 \%$ concentration in case of non- filtered effluent. However, when effluent was filtered with a coarse filter to remove filamentous microalgae, removal efficiency further increased to $18.17 \pm 6.71$ for $20 \%$ concentration, $17.64 \pm 6.71$ for $25 \%$ concentration, $22.27 \pm 5.68$ for $30 \%$ concentration, $19.98 \pm 6.62$ for $35 \%$ concentration, $18.44 \pm 5.52$ for $40 \%$ concentration and $18.69 \pm 5.51$ for $45 \%$ concentration as shown in Fig. 4(a). Variation in removal efficiency for TSS at different concentration considered in the study was $15.28 \pm 11.65$ for $20 \%$ concentration, $16.64 \pm 10.18$ for $25 \%$ concentration, $19.49 \pm 6.85$ for $30 \%$ concentration, $15.97 \pm 7.83$ for $35 \%$ concentration, $16.13 \pm 7.74$ for $40 \%$ concentration and $15.49 \pm 8.28$ for $45 \%$ concentration in case of non- filtered effluent. However, when effluent was filtered with a coarse filter to remove filamentous microalgae, removal efficiency further increased to $25.69 \pm 10.95$ for $20 \%$ concentration, $24.60 \pm 11.20$ for $25 \%$ concentration, $32.73 \pm 10.19$ for $30 \%$ concentration, $29.75 \pm 10.98$ for $35 \%$ concentration, $26.47 \pm$ 8.00 for $40 \%$ concentration and $25.51 \pm 7.89$ for $45 \%$ concentration as shown in Fig. $4(\mathrm{~b})$. The problem of separating algae from water may be solved by using attached algae because these attached algae are often observed in the form of algal biofilm in sufficient sunlight [34].

When compared to TS and TSS removal in TDS was low. Variation in removal efficiency for TDS at different concentration during the study was $7.29 \pm 3.99$ for $20 \%$ concentration, $7.11 \pm 4.53$ for $25 \%$ 
concentration, $5.83 \pm 2.64$ for $30 \%$ concentration, $4.48 \pm 2.11$ for $35 \%$ concentration, $3.62 \pm 1.59$ for $40 \%$ concentration and $5.45 \pm 2.39$ for $45 \%$ concentration in case of non- filtered effluent. However, when effluent was filtered with a coarse filter to remove filamentous microalgae increase in removal efficiency was observed up to $8.68 \pm 4.08$ for $20 \%$ concentration, $8.98 \pm 4.16$ for $25 \%$ concentration, $8.05 \pm 2.56$ for $30 \%$ concentration, $6.59 \pm 2.96$ for $35 \%$ concentration, $6.13 \pm 2.14$ for $40 \%$ concentration and $8.65 \pm 2.62$ for $45 \%$ concentration as shown in Fig. $5(\mathrm{a})$. Variation in removal efficiency for EC at different microalgal concentration was $6.95 \pm 4.27$ for $20 \%$ concentration, $6.4 \pm 3.69$ for $25 \%$ concentration, $7.27 \pm 6.97$ for $30 \%$ concentration, $5.68 \pm 6.28$ for $35 \%$ concentration, $3.88 \pm 2.51$ for $40 \%$ concentration and $5.49 \pm 3.35$ for $45 \%$ concentration in case of non- filtered effluent. However, when effluent was filtered with a coarse filter to remove filamentous microalgae, removal efficiency further increased $8.84 \pm 4.05$ for $20 \%$ concentration, $8.79 \pm 3.51$ for $25 \%$ concentration, $9.27 \pm 6.92$ for $30 \%$ concentration, $6.97 \pm 6.41$ for $35 \%$ concentration, $6.11 \pm 2.53$ for $40 \%$ concentration and $7.08 \pm 3.09$ for $45 \%$ concentration as shown in Fig. 5(b).

Microalgal system lead to increase in DO concentration, which raised up to $6.6 \mathrm{mg} / \mathrm{L}, 6.8 \mathrm{mg} / \mathrm{L}, 7.2 \mathrm{mg} / \mathrm{L}$, $7.6 \mathrm{mg} / \mathrm{L}, 7.6 \mathrm{mg} / \mathrm{L}$ and $7.8 \mathrm{mg} / \mathrm{L}$ respectively when influent was treated with microalgal concentration of $20 \%, 25 \%, 30 \%, 35 \%, 40 \%$ and $45 \%$ respectively. The increase in DO was mainly because of the photosynthetic effect of algae in addition to external aeration provided for the mixing of algae in the influent. Algal growth increases alkalinity to a remarkable level regardless of the initial $\mathrm{pH}$ [35]. The rise of $\mathrm{pH}$ by photosynthesis was impeded due to the production of $\mathrm{H}+$ ions by nitrification and by the use of ammonium as a nitrogen source for the photosynthesis process itself [36]. The elevated pH also enhances Ammonical- $\mathrm{N}$ removal. $\mathrm{pH}$ increased to 8.40 when treated with $20 \%$ microalgal concentration and 8.56 when treated with both $25 \%$ and $30 \%$ microalgae, whereas $\mathrm{pH}$ reached to $8.81,8.53$ and 8.57 when treated with $35 \%, 40 \%$ and $45 \%$ microalgal concentration respectively.

\section{Conclusions}

Algal treatment of wastewater, mediated through a combination of nutrient uptake, raised $\mathrm{pH}$ and high dissolved oxygen concentration, can offer an ecologically safe, cost-effective and efficient means to expel nutrients than conventional tertiary treatment. The study found that $30 \%$ concentration of Chlorella vulgaris is the optimum concentration among all the concentration studied to remove the nutrients, organic content and solids effectively with maximum removal efficiency greater than $90 \%$ without causing secondary sludge unlike other conventional and chemical treatments used for domestic wastewater treatment. Algae in wastewater can significantly contribute to the management of freshwater ecosystems by providing a more environmentally sound approach to deal with lessen eutrophication capacity of the point source.

\section{Declarations}


Availability of data and materials

Not applicable as all data generated or analyzed during this study are incorporated in the manuscript itself.

\section{Competing interests}

The authors declare they have no competing interests.

\section{Funding}

The authors fully acknowledged the support given by Technical Education Quality Improvement Programme Phase III, SVNIT Surat for providing financial support to collect the sample from various treatment plants of Surat city.

\section{Authors' contributions}

NM has done in detailed literature survey to find research gaps which lead to way for this study. She also collected samples, conducted all the experiments, along with data interpretation and statistical analysis single handedly during the study.

NDJ provided administrative and technical support in addition to critical comments and revisions in manuscript as being the co-supervisor for the study.

RAC administrative and technical support was given by him along with the critical comments for the experimental setup initially as well as during the study. Study was conducted under his supervision. All authors read and approved the final manuscript.

\section{Acknowledgements}

The authors wish to thankall those people who provided technical and non-technical support during the study.

\section{References}

1. Acien Fernandez FG, Gomez-Serrano C, Fernandez-Sevilla JM. Recovery of nutrients from wastewaters using microalgae. Front Sustain Food Syst. 2018;2:1-13.

2. Wang L, Liu J, Zhao Q, Wei W, Sun Y. Comparative study of wastewater treatment and nutrient recycle via activated sludge, microalgae and combination systems. Bioresour Technol. 2016;211:15.

3. Pradhan D, Sukla LB, Sawyer M, Rahman PKSM. Recent bioreduction of hexavalent chromium in wastewater treatment: A review. J Ind Eng Chem. 2017;55:1-20. 
4. Kumar KS, Dahms HU, Won EJ, Lee JS, Shin KH. Microalgae - A promising tool for heavy metal remediation. Ecotoxicol Environ Saf. 2015;113:329-52.

5. Saxena G, Chandra R, Bharagava RN. Environmental Pollution, Toxicity Profile and Treatment Approaches for Tannery Wastewater and Its Chemical Pollutants. Rev Environ Contam T. 2016;240:31-69.

6. Brenner K, You L, Arnold FH. Engineering microbial consortia: a new frontier in synthetic biology. Trend Biootechnol. 2008;26:483-9.

7. Whitton R, Le Mevel A, Pidou M, Ometto F, Villa R, Jefferson B. Influence of microalgal N and P composition on wastewater nutrient remediation. Water Res. 2016;91:371-8.

8. Wang JH, Zhang TY, Dao GH, Xu XQ, Wang XX, Hu HY. Microalgae-based advanced municipal wastewater treatment for reuse in water bodies. Appl Microbiol Biotechnol. 2017;101:2659-75.

9. Saeed T, Paul B, Afrin R, Al-Muyeed A, Sun G. Floating constructed wetland for the treatment of polluted river water: A pilot scale study on seasonal variation and shock load. Chem Eng J. 2016;287:62-73.

10. Rawat I, Kumar RR, Mutanda T, Bux F. Dual role of microalgae: Phycoremediation of domestic wastewater and biomass production for sustainable biofuels production. Appl Energy. 2011;88:3411-24.

11. Bhattacharjee M, Siemann E. Low algal diversity systems are a promising method for biodiesel production in wastewater fed open reactors. Algae. 2015;30:67-79.

12. Malik N. Biotechnological potential of immobilised algae for wastewater N, P and metal removal: a review. Biometals. 2002;15:377-90.

13. Wang M, Kuo-Dahab WC, Dolan S, Park C. Kinetics of nutrient removal and expression of extracellular polymeric substances of the microalgae, Chlorella sp. and Micractinium sp. in wastewater treatment. Bioresour Technol. 2014;154:131-7.

14. Aslan S, Kapdan IK. Batch kinetics of nitrogen and phosphorus removal from synthetic wastewater by algae. Ecol Eng. 2006;28:64-70.

15. Ruiz-marin A, Mendoza-espinosa LG, Stephenson T. Growth and nutrient removal in free and immobilized green algae in batch and semi-continuous cultures treating real wastewater. Bioresour Technol. 2010;101:58-64.

16. Ruiz J, Alvarez P, Arbib Z, Garrido C, Barragan J, Perales JA. Effect of nitrogen and phosphorus concentration on their removal kinetic in treated urban wastewater by Chlorella vulgaris. Int $\mathrm{J}$ Phytoremediat. 2011;13:884-96.

17. Lee CS, Lee SA, Ko SR, Oh HM, Ahn CY. Effects of photoperiod on nutrient removal, biomass production, and algal-bacterial population dynamics in lab-scale photobioreactors treating municipal wastewater. Water Res. 2015;68:680-91.

18. Li Y, Chen Y, Chen P, Min M, Zhou W, Martinez B, et al. Characterization of a microalga Chlorella sp. well adapted to highly concentrated municipal wastewater for nutrient removal and biodiesel production. Bioresour Technol. 2011;102:5138-44. 
19. Choi HJ, Lee SM. Effects of microalgae on the removal of nutrients from wastewater: Various concentrations of Chlorella vulgaris. Environ Eng Res. 2012;17:3-8.

20. Henkanatte-Gedera SM, Selvaratnam T, Karbakhshravari M, Myint M, Nirmalakhandan N, Voorhie WV, Lammers PJ. Removal of dissolved organic carbon and nutrients from urban wastewaters by Galdieria sulphuraria: Laboratory to field scale demonstration. Algal Res. 2017;24:450-6.

21. Samori G, Samori C, Pistocchi R. Nutrient Removal Efficiency and Physiological Responses of Desmodesmus communis at Different HRTs and Nutrient Stress Condition Using Different Sources of Urban Wastewater Effluents. Appl Biochem Biotechnol. 2014;173:74-89.

22. Sharma G, Khan S. Bioremediation of Sewage Wastewater Using Selective Algae for Manure Production. Ripublication Com. 2013;4:573-80.

23. Sydney EB, da Salva TE, Tokarski A, Novak AC, de Carvalho JC, Woiciecohwski AL, et al. Screening of microalgae with potential for biodiesel production and nutrient removal from treated domestic sewage. Appl Energy. 2011;88:3291-94.

24. Satpal S, Khambete AK. Waste Water Treatment Using Micro-Algae - A review paper. Int J Eng Technol Manag Appl Sci. 2016;4:1-5.

25. Christenson L, Sims R. Production and harvesting of microalgae for wastewater treatment, biofuels, and bioproducts. Biotechnol Adv. 2011;29:686-702.

26. Markou G, Georgakakis D. Cultivation of filamentous cyanobacteria (blue-green algae) in agroindustrial wastes and wastewaters: A review. Appl Energy. 2011;88:3389-401.

27. Cai T, Park SY, Li Y. Nutrient recovery from wastewater streams by microalgae: Status and prospects. Renew Sustain Energy Rev. 2013;19:360-69.

28. Sanz-Luque E, Chamizo-Ampudia A, Llamas A, Galvan A, Fernandez E. Understanding nitrate assimilation and its regulation in microalgae. Front Plant Sci. 2015;6:899-15.

29. Wagner M, Loy A. Bacterial community composition and function in sewage treatment systems. Curr Opin Biotechnol. 2002;13:218-27.

30. Martínez ME, Jimenez JM, El Yousfi F. Influence of phosphorus concentration and temperature on growth and phosphorus uptake by the microalga Scenedesmus obliquus. Bioresour Technol. 1999;67:233-40.

31. Acien FG, Gomez-Serrano C, Morales-Amaral MM, Fernandez-Sevilla JM, Molina-Grima E. Wastewater treatment using microalgae: how realistic a contribution might it be to significant urban wastewater treatment? Appl Microbiol Biotechnol. 2016;100:9013-22.

32. Subashchandrabose SR, Ramakrishnan B, Megharaj M. Consortia of cyanobacteria / microalgae and bacteria: Biotechnological potential. Biotechnol Adv. 2011;29:896-907.

33. Han P, Lu Q, Fan L, Zhou W. A review on the use of microalgae for sustainable aquaculture. Appl Sci. 2019;9:2377-97.

34. He S, Xue G. Algal-based immobilization process to treat the effluent from a secondary wastewater treatment plant (WWTP). J Hazard Mater. 2010;178:895-99. 
35. Kube M, Jefferson B, Fan L, Roddick F. The impact of wastewater characteristics, algal species selection and immobilisation on simultaneous nitrogen and phosphorus removal. Algal Res. 2018;31:478-88.

36. Schumacher G, Sekoulov I. Improving the effluent of small wastewater treatment plants by bacteria reduction and nutrient removal with an algal biofilm. Water Sci Technol. 2003;48:373-80.

\section{Tables}

Table 1 Raw wastewater characteristics for the study with different microalgal concentration

\begin{tabular}{|c|c|c|c|}
\hline Parameter & Set $1(20 \%$ and $25 \%)$ & Set $2(30 \%$ and $35 \%)$ & Set $3(40 \%$ and $45 \%)$ \\
\hline $\mathrm{pH}$ & $7.24 \pm 0.23$ & $7.16 \pm 0.21$ & $7.32 \pm 0.29$ \\
\hline $\mathrm{EC}(\mathrm{mS} / \mathrm{cm})$ & $2.18 \pm 0.13$ & $2.23 \pm 0.22$ & $2.18 \pm 0.23$ \\
\hline TDS (mg/L) & $1133.33 \pm 127.52$ & $1120.83 \pm 97.37$ & $1090.83 \pm 118.36$ \\
\hline TSS (mg/L) & $1429.50 \pm 265.43$ & $1587.50 \pm 254.49$ & $1682.42 \pm 242.95$ \\
\hline $\mathrm{TS}(\mathrm{mg} / \mathrm{L})$ & $2587.83 \pm 306.08$ & $2699.33 \pm 295.42$ & $2719.25 \pm 282.74$ \\
\hline $\mathrm{COD}(\mathrm{mg} / \mathrm{L})$ & $251.80 \pm 46.81$ & $281.6 \pm 26.00$ & $285.60 \pm 22.96$ \\
\hline Phosphate (mg/L) & $2.44 \pm 0.71$ & $2.81 \pm 0.42$ & $2.42 \pm 0.48$ \\
\hline Ammonia (mg/L) & $11.16 \pm 1.12$ & $12.54 \pm 1.68$ & $13.72 \pm 2.43$ \\
\hline Nitrate $(\mathrm{mg} / \mathrm{L})$ & $0.97 \pm 0.36$ & $1.05 \pm 0.34$ & $0.96 \pm 0.34$ \\
\hline $\mathrm{DO}(\mathrm{mg} / \mathrm{L})$ & $0.13 \pm 0.16$ & $0.14 \pm 0.16$ & $0.11 \pm 0.14$ \\
\hline
\end{tabular}

\section{Figures}



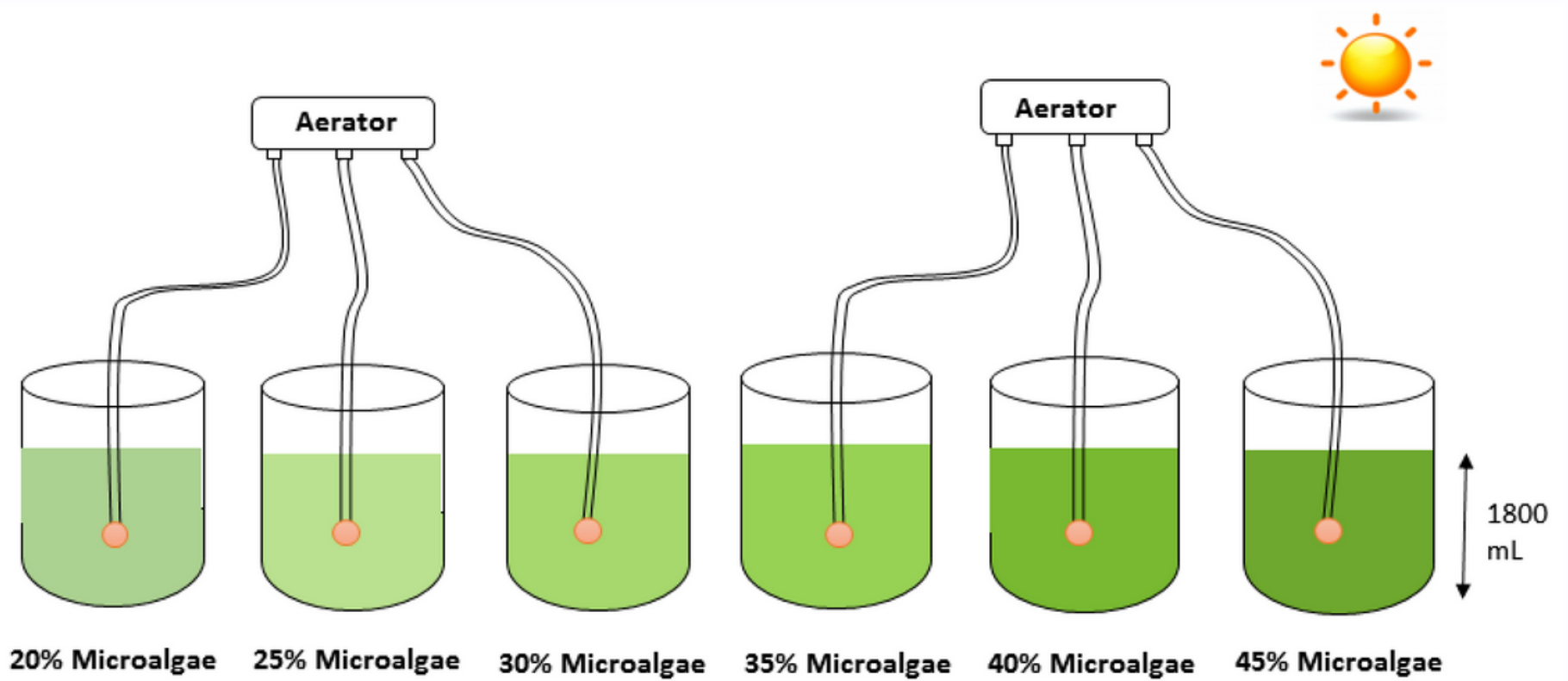

Figure 1

Pictorial view of experimental setup

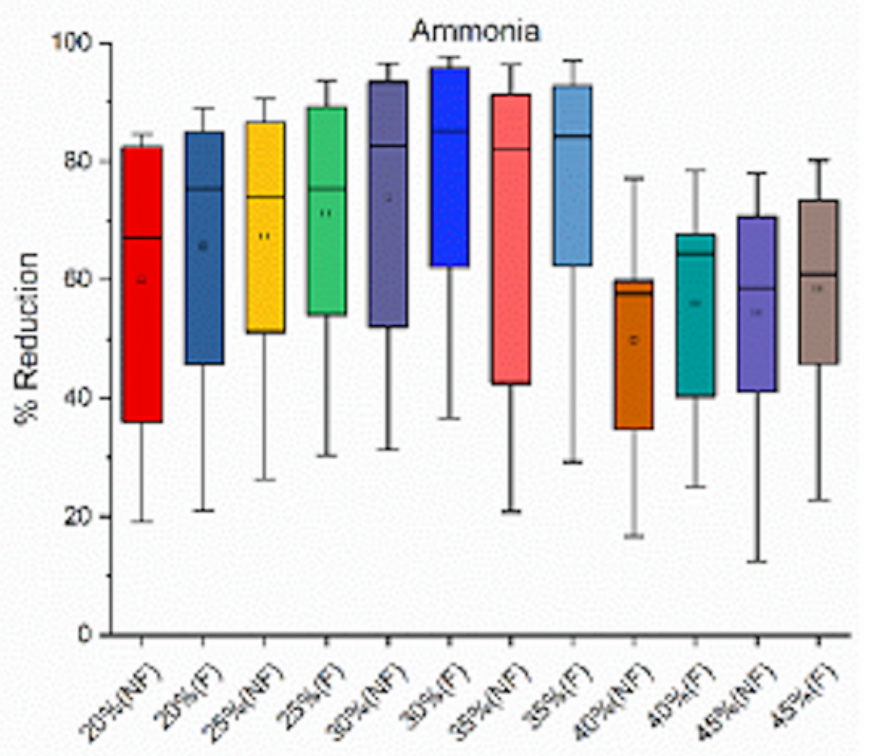

(a)

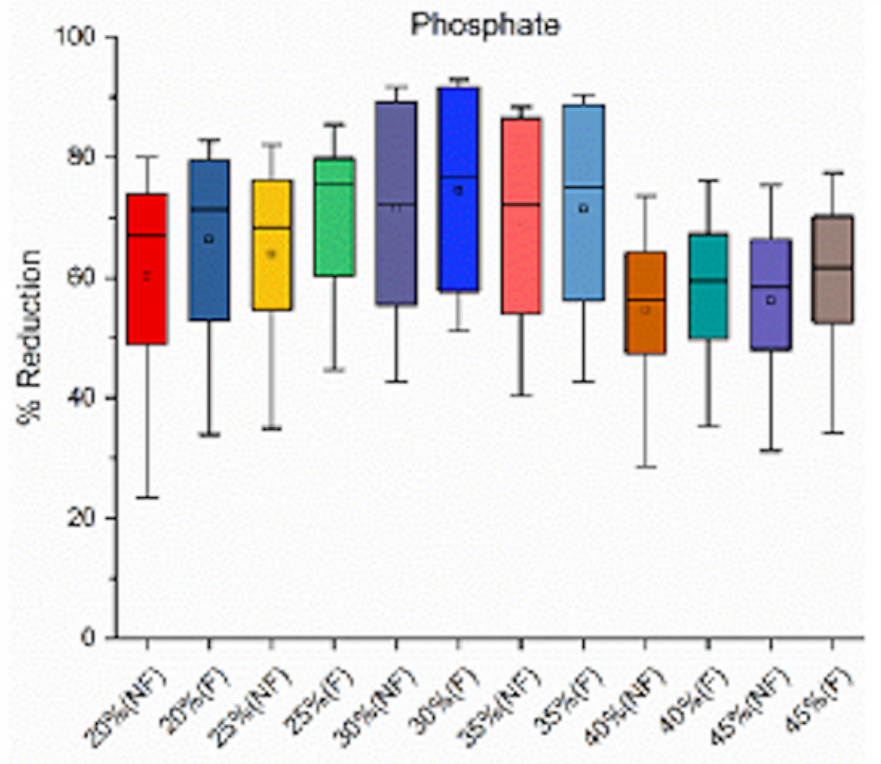

(b)

Figure 2

Variation in removal efficiency in (a) Ammonia and (b) Phosphate at different microalgal concentration 


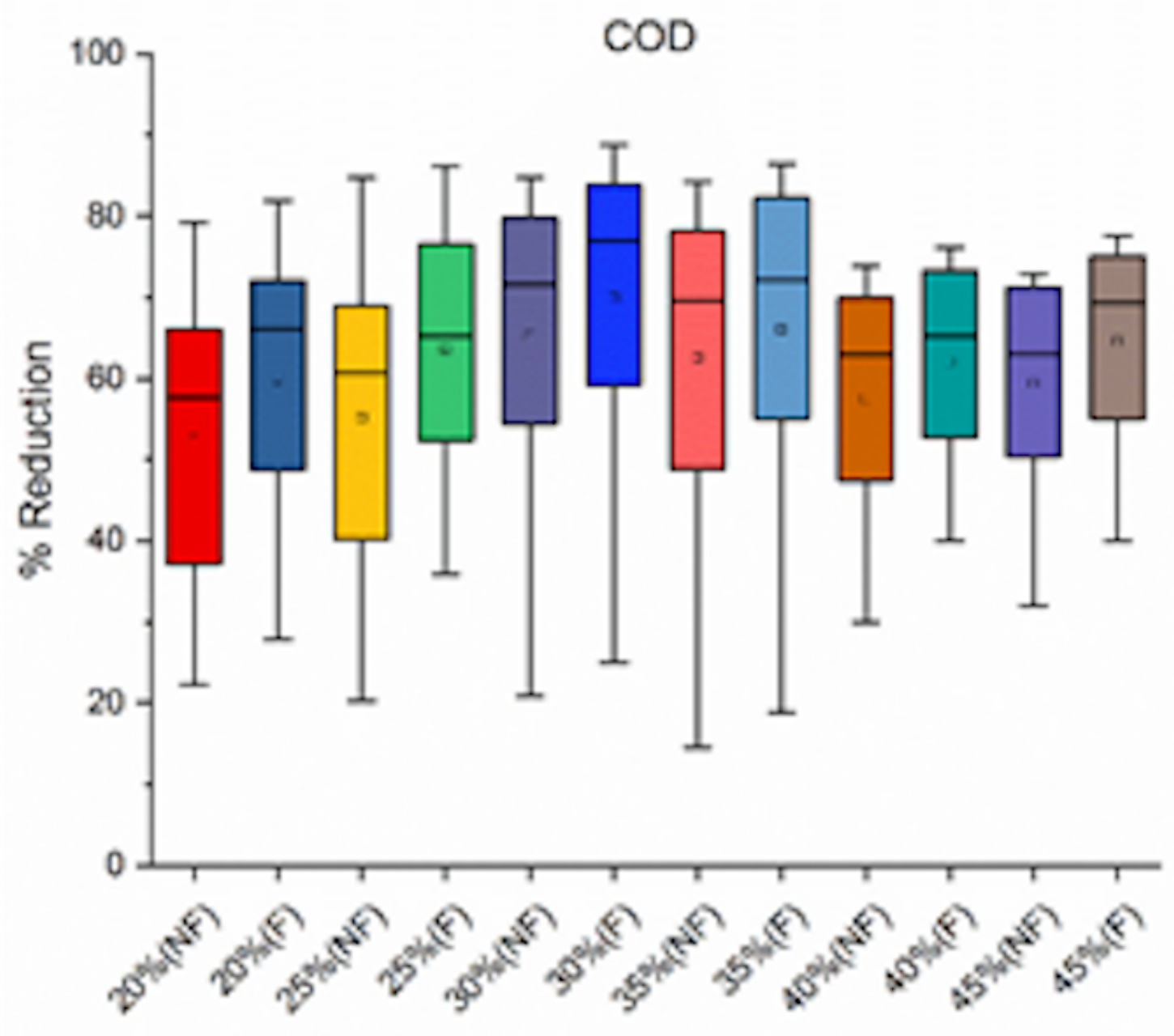

Figure 3

Variation in removal efficiency in COD at different microalgal concentration 


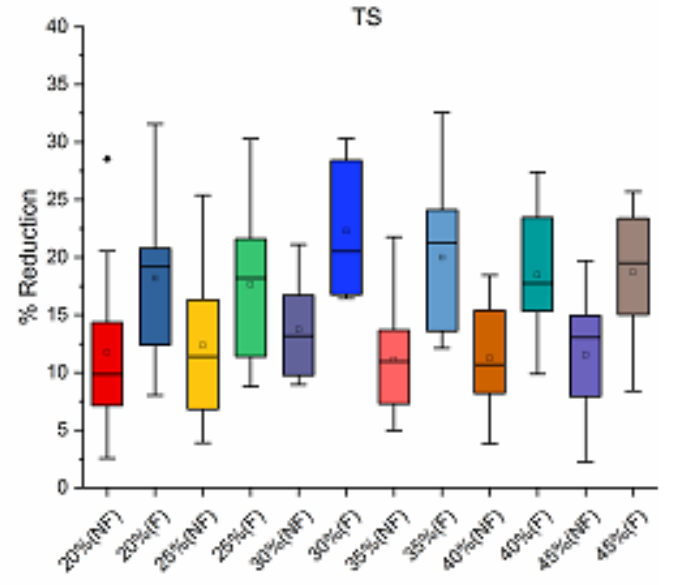

(a)

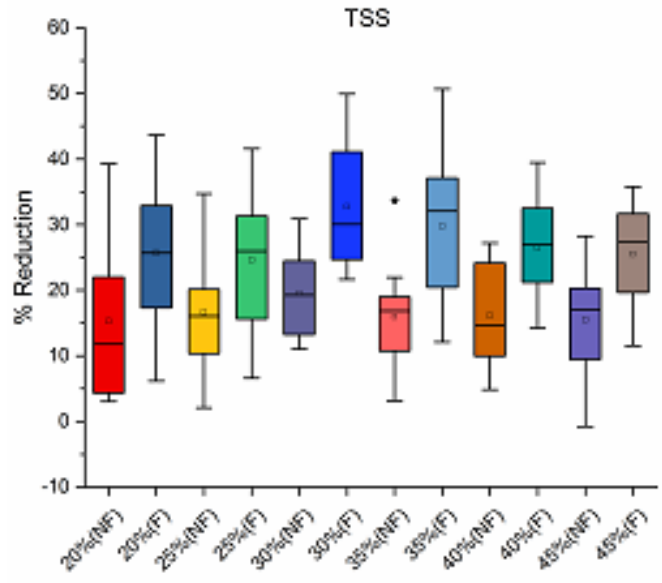

(b)

Figure 4

Variation in removal efficiency in (a) TS and (b) TSS at different microalgal concentration

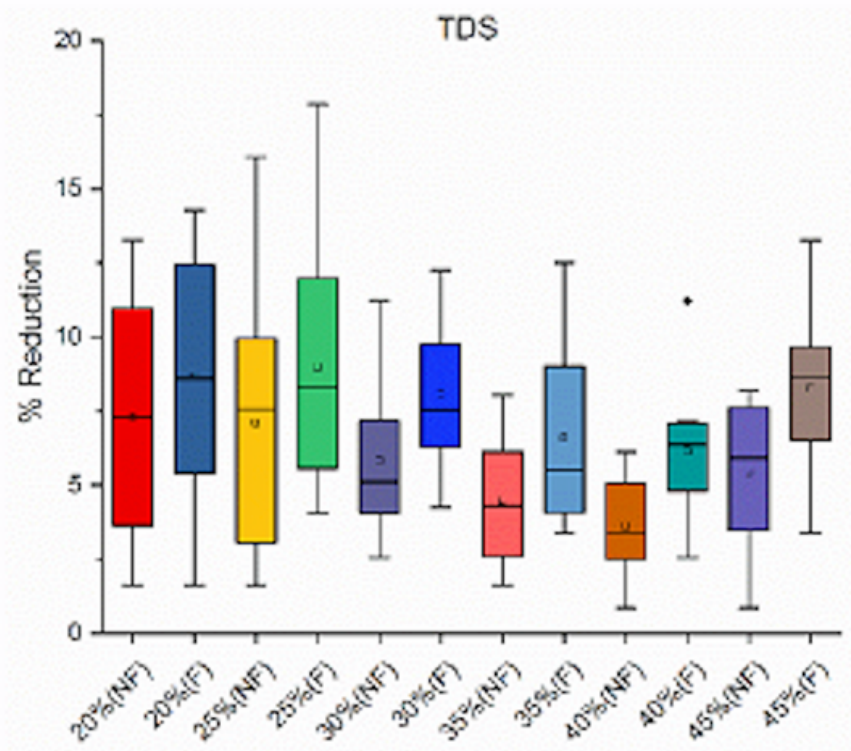

(a)

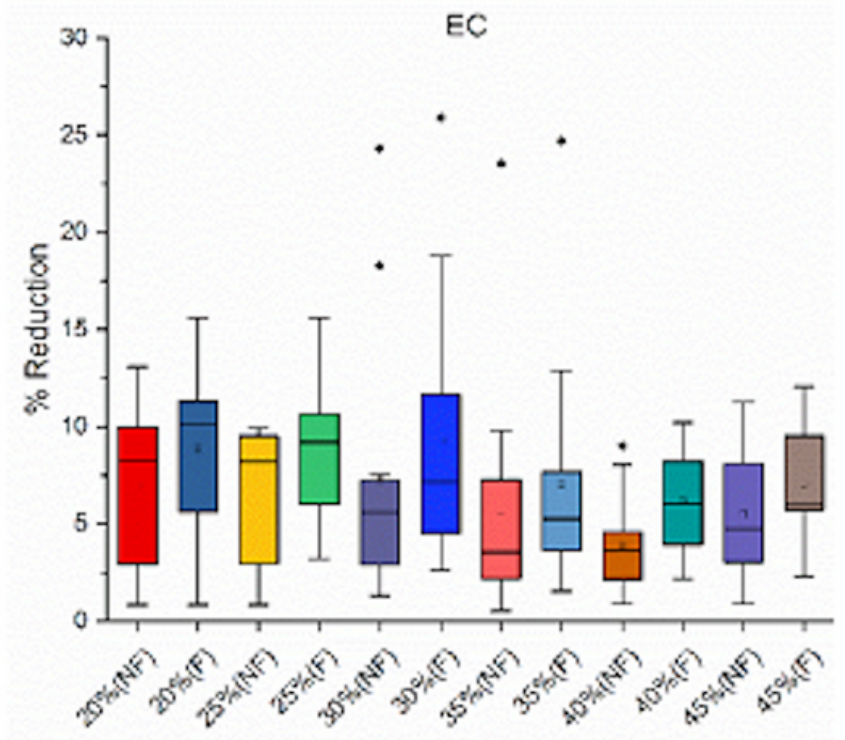

(b)

Figure 5

Variation in removal efficiency in(a) TDS and (b) EC at different microalgal concentration 